\title{
Retraction Note to: In vitro clonal propagation of annatto (Bixa orellana L.)
}

\author{
Marie-Claire D'Souza $^{1} \cdot$ Madhuri Sharon $^{1}$
}

Published online: 11 January 2017

(C) The Society for In Vitro Biology 2016

Retraction Note To: In Vitro Cell. Dev. Biol.-Plant

DOI 10.1007/s11627-001-0029-7

This paper is being retracted by the Editor-in-Chief because it contains extensive figure and data duplication from an article published in Current Science, Vol 78, No 12, June 2000, pp 1532-1535.

The online version of the original article can be found at http://dx.doi. org/10.1007/s11627-001-0029-7.

\footnotetext{
Madhuri Sharon garef.tcl@mailcity.com

1 Gufic Applied Research and Education Foundation, Gufic Bldg, 11th Road, MIDC, Marol, Andheri (E), Mumbai 400 093, India
} 